\title{
The National Volcano Early Warning System (NVEWS)
}

\author{
Within the United States, numerous \\ volcanoes threaten people, property, \\ and infrastructure on the ground, as \\ well as aircraft in the skies. Many \\ hazardous volcanoes currently are \\ undermonitored, have antiquated \\ monitoring systems, or have no ground- \\ based monitoring at all.
}

\section{NVEWS aims to reduce vulnerability to} volcanic hazards by providing:

- Robust, real-time monitoring of the most threatening of the Nation's volcanoes

- A 24/7 Volcano Watch Office

- Improved research collaboration between Federal and academic scientists

- A National Volcano Data Center

- High-quality data sets for volcanological research

\section{NVEWS addresses the disaster reduction goals articulated by the Subcommitee on Disaster Reduction of the National Science and Technology Council' :}

- Providing hazard and disaster information where and when it is needed

- Understanding the natural processes that produce hazards

- Developing hazard mitigation strategies and technologies

- Recognizing and reducing vulnerability of infrastructure

- Assessing disaster resilience

- Promoting risk-wise behavior

${ }^{1}$ National Science and Technology Council, 2005, Grand challenges for disaster reduction: A report of the Subcommittee on Disaster Reduction: Washington, D.C., 21 p. (http://www.sdr.gov/SDRGrandChallenges forDisasterReduction.pdf)

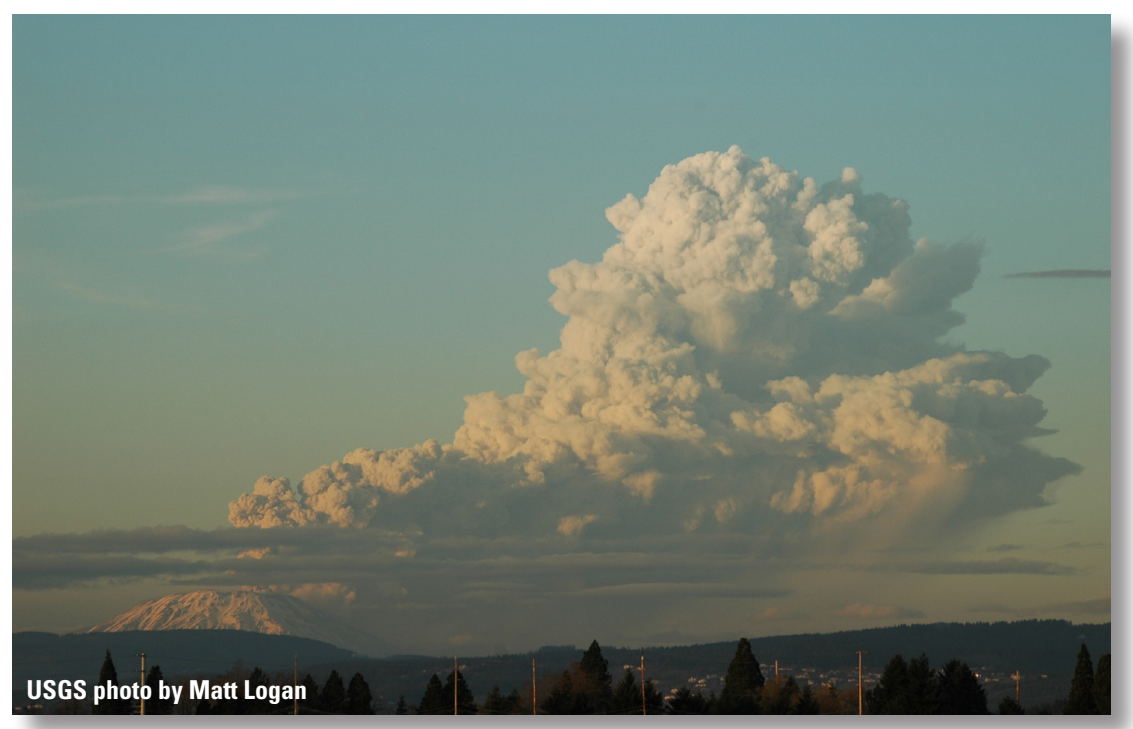

March 8, 2005, eruption of Mount St. Helens. After 18 years of quiet, Mount St. Helens reawakened in September 2004 with a swarm of earthquakes and rapid deformation of the crater floor. Within days, the volcano was producing minor steam and ash eruptions; after only 18 days, the first lava reached the surface. Although monitoring instrumentation was sufficient to detect the obvious onset of seismic unrest, much of the equipment and telemetry had been installed more than 20 years previously, and their limitations soon became evident. For example, as earthquake activity increased, many seismic signals went off scale, limiting diagnostic capabilities. Telemetered deformation instruments could not be installed quickly enough to capture the deformation signal as magma rose to the surface. Additional monitoring instrumentation had to be installed quickly as the USGS Cascades Volcano Observatory and CUSVO partner University of Washington/Pacific Northwest Seismic Network reacted to the escalating activity while a potentially hazardous situation rapidly unfolded.

\section{Volcanic Threat and Monitoring Capabilities in the United States}

The National Volcano Early Warning System (NVEWS) is a proposed nationalscale effort by the U.S. Geological Survey (USGS) Volcano Hazards Program and its affiliated partners in the Consortium of U.S. Volcano Observatories (CUSVO) (http://www.cusvo.org) to ensure that volcanoes are monitored at a level commensurate with the threats they pose. Roughly half of the Nation's 169 young volcanoes are dangerous because of the manner in which they erupt and the communities and infrastructure within their destructive reach. Most U.S. volcanoes are located on sparsely populated Federal lands, but it is the threat to communities and infrastructure downstream and downwind, including to military and commercial aviation, that drives the need to properly monitor volcanic activity and provide forecasts and notifications of expected hazards.

Waiting until unrest escalates at a volcano then reacting to improve sparse monitoring arrays results in the loss of precious time and data as scientists, civil authorities, citizens, and businesses play "catch up" with a dangerous force of nature. NVEWS is a proposal to address monitoring needs at potentially dangerous volcanoes that have inadequate ground-based monitoring or none at all and to move beyond a reactive approach to mitigating volcanic risk. The most hazardous volcanoes would be properly monitored well in advance of the onset of activity, making it possible for scientists to improve the timeliness and accuracy of hazard forecasts and for citizens to take proper and timely action to reduce risk.

The first step in developing NVEWS was a systematic assessment of (1) threats posed by U.S. volcanoes to human life and enterprise, (2) current monitoring capabilities at each volcano, and (3) improvements necessary to fill the worst monitoring gaps. The NVEWS assessment, published in 2005 (http://pubs.usgs.gov/of/2005/1164/), shows that a few volcanoes are relatively 
well monitored with telemetered instrument arrays of various types. Many other volcanoes are monitored primarily by a network of sparsely distributed seismic instruments that lack the sensitivity to detect the subtle earthquakes that commonly characterize the earliest stages of unrest. Some hazardous volcanoes have no ground-based monitoring whatsoever.

The overall result of the NVEWS assessment is the identification of 57 priority volcanoes that are undermonitored for the threats posed and thus targets for improved monitoring networks (see table).

\section{Framework for a National Volcano Early Warning System}

An effective monitoring and hazardwarning system will generate timely and accurate identification of the hazards and provide mechanisms to inform people so that they can take action to mitigate the impact of the hazardous phenomena. More than a network of instruments, NVEWS connects the monitoring and research efforts of scientists to the emergency managers and general public at both national and local levels to minimize the impact of volcanic activity on the Nation. NVEWS provides a common framework for coordinating the collection and dissemination of data among all relevant Federal agencies, academic partners, and the general public.

Expanded Volcano Monitoring. An increase in the scope and scale of volcano monitoring in the United States will form the basis of more reliable eruption forecasts and warnings. The much richer body of observations and data on volcanic activity that would become available with NVEWS will foster innovative and multidisciplinary research that provides the scientific underpinnings of accurate forecasts of volcanic behavior.

External Grants Program. Under NVEWS, an external grants program administered by the USGS Volcano Hazards Program would fund needed research on hazardous phenomena and risk mitigation. Such a program would enhance collaboration between USGS and external researchers and increase the breadth of expertise brought to bear on reducing volcanic risk.

\section{National Volcano Data Center. A} system for organizing and sharing diverse data related to volcano hazards would be established so that pertinent information will be accessible for researchers and response managers.

24/7 Volcano Watch Office. A USGS Volcano Watch Office operating 24 hours

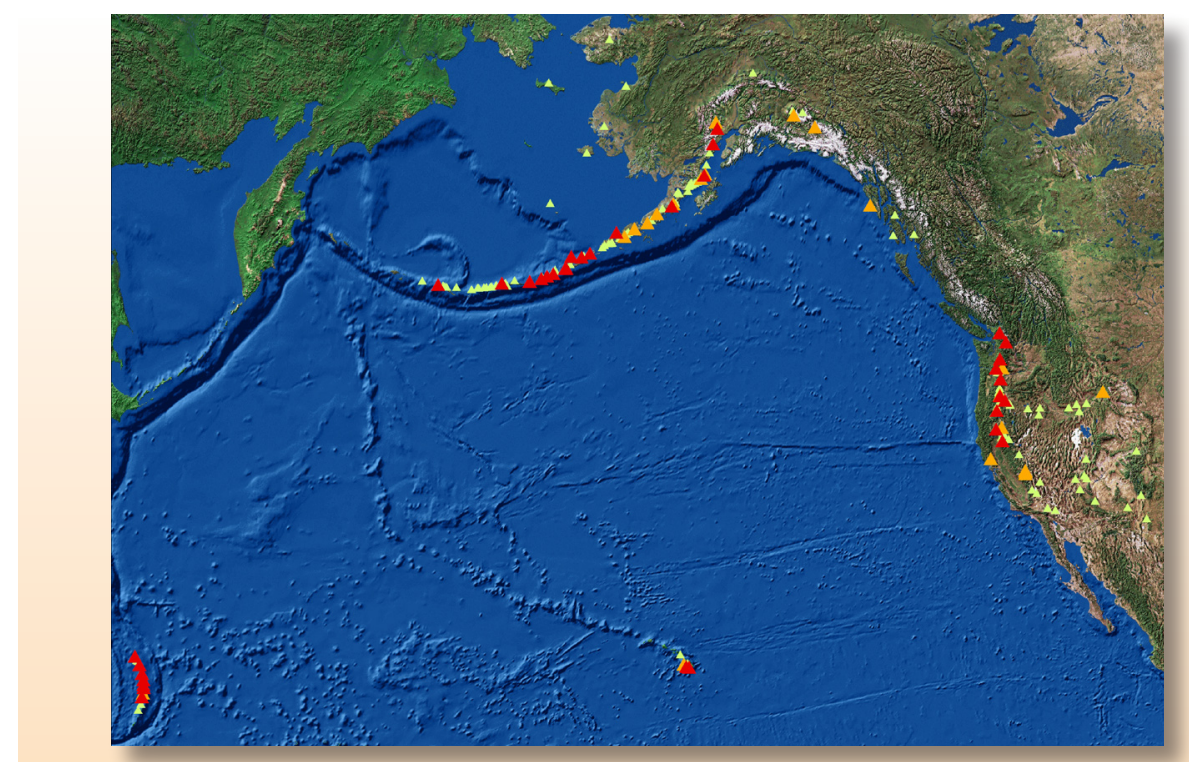

US VOLCANOES and NVEWS Targets The United States has the largest number of young volcanoes capable of erupting of any country in the world. In the past 26 years, 47 eruptions and at least 17 episodes of significant unrest have occurred at 34 different volcanoes. The United States has five volcano observatories (Alaska, Cascades, Hawaiian, Long Valley, and Yellowstone) supported primarily by the USGS Volcano Hazards Program that relies on staff and facilities of the USGS and affiliated academic institutions and State and Federal agencies. Red triangles are the 35 highest-priority NVEWS targets; orange triangles are the 22 highpriority targets; small green triangles are other U.S. volcanoes.

\begin{tabular}{|c|c|c|}
\hline & Highest Priority & High Priority \\
\hline Alaska & $\begin{array}{l}\text { Akutan, Amak, Amukta, Augustine, } \\
\text { Bogoslof, Cleveland, Fourpeaked, } \\
\text { Kasatochi, Kiska, Makushin, } \\
\text { Recheschnoi, Redoubt, Seguam, } \\
\text { Vsevidof, Yantarni, Yunaska }\end{array}$ & $\begin{array}{l}\text { Black Peak, Chiginagak, Churchill, } \\
\text { Dana, Douglas, Dutton, Edge- } \\
\text { cumbe, Hayes, Kaguyak, Kupre- } \\
\text { anof, Mount Spurr, Wrangell }\end{array}$ \\
\hline Washington & $\begin{array}{l}\text { Glacier Peak, Mount Baker, Mount } \\
\text { Rainier, Mount St. Helens }\end{array}$ & Mount Adams \\
\hline Oregon & $\begin{array}{l}\text { Crater Lake, Mount Hood, } \\
\text { Newberry, South Sister }\end{array}$ & North Sister Field \\
\hline California & Lassen Peak, Mount Shasta & $\begin{array}{l}\text { Clear Lake, Inyo Craters, Mono Cra- } \\
\text { ters, Mono Lake Field, Medicine Lake }\end{array}$ \\
\hline Wyoming & & Yellowstone \\
\hline Hawaii & Kilauea, Mauna Loa & Hualalai \\
\hline $\begin{array}{l}\text { Commonwealth of } \\
\text { N. Mariana Islands }\end{array}$ & $\begin{array}{l}\text { Agrigan, Alamagan, Ana- } \\
\text { tahan, Asuncion, Farallon } \\
\text { de Pajaros, Guguan, Pagan }\end{array}$ & Sarigan \\
\hline
\end{tabular}

a day 7 days a week would extend the capabilities of the five U.S. Volcano Observatories to provide forecasts, alerts, and authoritative information on volcanic unrest and eruptive activity throughout the United States and selected regions abroad. Establishing a Watch Office would put the U.S. Volcano Observatories on the same roundthe-clock operational footing as important partners and clientele.

\section{Reducing Community Vulnerabil-} ity. A major objective of NVEWS is to build on the current level of community outreach, including creating informationdelivery systems that will allow customers, partners, cooperators, and the public to find and understand the information that they need about volcanic hazards.
If fully implemented, NVEWS promises to provide hazard information where and when it is needed as well as improve understanding of the natural processes that produce volcanic hazards.

\section{John Ewert, Marianne Guffanti, Peter Cervelli, and James Quick}

For more information contact:

U.S. Geological Survey

Volcano Hazards Program Office 12201 Sunrise Valley Drive

Reston, VA 20192

Tel.: (703) 648-6711 Fax: (703)648-5483

http://volcanoes.usgs.gov 